\title{
A GLOBALIZAÇÃo ATRAVÉS DE UMA NOVA PERSPECTIVA
}

Hugo Leonardo Guilhernandes Cardozo hugogcardozo@gmail.com

Mestrando em Administração pelo Programa de Pós-Graduação em Administração, Universidade Unigranrio - Rio de Janeiro RJ, Brasil

Josir Simeone Gomes josirgomes@superig.com.br

Professor do Programa de Pós-Graduação em Administração, Universidade Unigranrio - Rio de Janeiro - RJ, Brasil

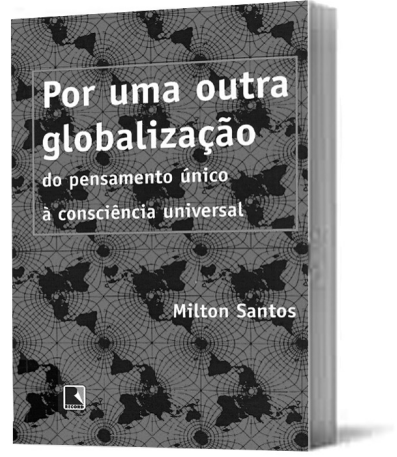

\section{POR UMA OUTRA GLOBALIZAÇÃO (do pensamento único à consciência universal)}

De Milton Santos. Rio de Janeiro: Record, 2000. 174 p.

A globalização é considerada um fenômeno capitalista que parece ter surgido na era dos grandes descobrimentos e experimentou um grande desenvolvimento a partir da Revolução Industrial. Durante um longo período seu conteúdo passou despercebido, sendo abordado nos dias atuais por diversos economistas que analisam a globalização como resultado do pós-guerra, sendo decorrente da revolução da tecnologia da informação. Segundo Joseph E. Stiglitz (2000), Prêmio Nobel de
Economia 2001: "Para a maior parte do mundo a globalização, como tem sido conduzida, assemelha-se a um pacto com o demônio. Algumas pessoas nos países ficam mais ricas, as estatísticas do PIB - pelo valor que possam ter - aparentam melhoras, mas o modo de vida e os valores básicos da sociedade ficam ameaçados. Isto não é como deveria ser." Já Paul Singer vê a globalização como fruto da expansão comercial e marítima europeia, da mesma forma como se deu o desenvolvimento do capitalismo, enquanto Maria da Conceição Tavares atribui seu surgimento à expansão do mercado financeiro, que deu origem a novos produtos financeiros.

Neste livro o autor Milton Santos analisa e aponta as dificuldades e vantagens da interação com um mundo globalizado, o que leva a uma discussão referente aos paradigmas surgidos na era da globalização e sua relevância no Estado capitalista.

Como uma das perspectivas, o autor destaca a ideia da existência de uma aldeia global que encurta as distâncias, onde as pessoas começam a participar de "um único mundo sem fronteiras". Dentro deste mundo globalizado, os integrantes experimentam as vantagens do desenvolvimento tecnológico, social, econômico e crescimento cultural e as desvantagens da perversidade do capitalismo, multiplicação de problemas socioeconômicos (fome, desemprego, deseducação formal etc.), a separação e descriminação das classes sociais e o aumento da miséria e pobreza.

Na perspectiva de fábula, o autor idealiza o mito da aldeia global, fazendo crer na difusão instantânea de notícias, procurando caracterizar o planeta como um grande espaço marcado pela homogeneização técnica, que procura fazer com que uma parcela considerável da população mundial acredite que participa de "um único mundo". O encurtamento das distâncias difunde a noção de tempo e espaço contraídos, como se o mundo estivesse ao alcance da mão de todos.

O mercado global é capaz de homogeneizar o planeta, com o desenvolvimento por meio do livre comércio e da completa liberdade de circulação dos capitais privados, o que acabaria conduzindo a humanidade na direção de um governo global, ocorrendo a morte do Estado. Entretanto, o que aconteceu foi o seu fortalecimento para atender 
aos reclamos da finança e de interesses internacionais, em detrimento dos cuidados com as populações cuja vida torna-se mais difícil.

$\mathrm{O}$ autor menciona que a globalização é para todos, porém para se tornar um ser globalizado é necessário ter um mínimo desenvolvimento tecnológico. E podemos caracterizar diferenças entre os Estados devido a sua entrada no mundo globalizado. Muitos Estados tiveram uma demora na aceitação e no crescimento de sua estrutura tecnológica, o que atrasou a entrada da internet, criando diferenças entre eles, ou seja, os Estados mais desenvolvidos conseguiram entrar primeiro na globalização, levando vantagens competitivas. Como exemplo, a tecnologia $4 \mathrm{G}$ de transmissão, que já está em pleno funcionamento na Europa, Japão e USA, no Brasil ainda encontram-se dificuldades com as instalações da tecnologia 3G. Segundo matéria publicada na revista INFO Online (2012), as empresas responsáveis alegam que para a instalação da $4 \mathrm{G}$ o desembolso para adquirir esta tecnologia vai custar caro para os usuários, e com previsão do prazo de instalação para 2014, somente nas capitais onde ocorrerá a Copa.

Mesmo assim, segundo o autor, o ser social globalizado encontra várias vantagens para seu crescimento cultural, pois devido às quebras das fronteiras as informações mundiais podem ser acessadas com mais rapidez e facilidade, aprimorando o conhecimento. Por outro lado, a quantidade de informações e a velocidade em que aparecem dificultam a sua integração com a sociedade e, com isto, o usuário das informações necessita de um descanso, um desligamento para uma melhor qualidade de vida, retornando ao mercado com uma melhor disposição e um melhor nível de criatividade. O autor enfatiza que o ser globalizado precisa deste descanso de informações e um momento de distração fora deste mundo sem fronteiras, com o objetivo de melhorar sua interação com a sociedade, em um momento de ócio para o seu desenvolvimento filosófico.

A outra perspectiva da globalização idealizada pelo autor é a fábrica de perversidades. Segundo Milton Santos, as perversidades encontradas no mundo globalizado ocorrem devido às facilidades de minimizar os custos e maximizar os lucros, mesmo que este custo prejudique toda uma classe social. Tomando como exemplo uma matéria de Lucianne Carneiro, publicada pelo jornal O Globo, no caderno de economia no dia 08/04/2012, intitulada "Rua Teresa made in China". Esta matéria demonstra que as confecções tradicionais e fábricas de tecidos que foram criadas por volta de 1870 passaram a ter 20\% de suas vendas representadas por mercadorias produzidas na China. Isto significa que estas confecções deixaram de fabricar em decorrência do elevado custo, encontrando como solução a compra de mercadorias mais baratas e que elevaram sua margem de lucro, mas que levou à destruição do parque fabril e dos empregos de seus funcionários. Situações idênticas a esta ocorrem no mundo globalizado, o aumento do desemprego tornando-se crônico, a pobreza aumentando e as classes médias perdendo qualidade de vida, o salário médio tendendo a baixar e a fome e o desabrigo crescendo em todo o continente.

A terceira perspectiva de globalização para o autor é aquela que dá nome à sua obra, ou seja, a possibilidade de outra globalização, que aconteceria com um caráter mais humano e solidário. O autor demonstra acreditar numa mudança que aconteceria de baixo para cima, partindo dos países subdesenvolvidos, dos deserdados e a partir do exercício do pensamento livre, com o conhecimento e a unicidade do planeta utilizados para outros objetivos.

Esta utopia vem sendo insistentemente negada pelos fatos, já que as consequências socioeconômicas do processo real de globalização são completamente distintas, dependendo do território e do poder dos Estados. Entretanto, o autor acredita que com essas bases técnicas nas quais o grande capital se apoia seja possível construir a globalização que poderá servir a novos objetivos, se forem postos a serviço de outros fundamentos sociais e políticos.

O autor também menciona que a utopia poderia ocorrer para reduzir as condições de competitividade entre os países, abolindo algumas condições, com a inclusão das populações mais miseráveis e pobres. Mas, como podemos perceber, esta utopia terá que superar várias barreiras para sua implementação, na qual buscaremos outros caminhos para a inclusão destas classes. Um desses caminhos poderia se dar através de pressão popular por uma melhor educação pública para a população.

O livro traz importantes contribuições para os leitores interessados nas transformações profundas nos sistemas sociais, estimulando estratégias no controle das organizações a uma necessidade de uma estratégia de inter-relacionamento de todos os seus recursos. Expondo uma reflexão sobre o capitalismo aos conceitos sustentáveis para a concretização da tentativa descrita como utopia para Milton Santos, onde a mensagem e a esperança na construção de um novo universalismo.

Finalmente, o livro pode ajudar estudiosos, pesquisadores e profissionais a compreender o fenômeno da globalização através de uma nova perspectiva que não aquela discutida pelos economistas. 